\title{
Effect of Different Seed Sizes and Seed Rates on the Growth and Productivity of Wheat Grown Under Semi-Arid Conditions
}

\author{
Muhammad Shoaib $^{1 *}$, Muhammad Nawaz ${ }^{2}$, Muhammad Ilyas ${ }^{3}$, Muhammad Shafique $^{1}$, Imran Khan ${ }^{*}$, \\ Muhammad Talha Aslam ${ }^{1}$, Muhammad Sultan Ali Bazmi ${ }^{4}$, Muhammad Arshad ${ }^{5}$, Ghulam Ahmad ${ }^{4}$, \\ Muhammad Irfan ${ }^{6}$, Muhammad Umer Chattha ${ }^{1}$ and Muhammad Umair Hassan ${ }^{1}$
}

${ }^{1}$ Department of Agronomy, University of Agriculture, Faisalabad, 38040, Pakistan; ${ }^{2}$ Department of Agricultural Engineering, Khwaja Fareed University of Engineering and Information Technology, Rabim Yar Khan 64200, Pakistan; ${ }^{3}$ University College of Dera Murad Jamali Nasirabad (LUAWMS), Pakistan; ${ }^{4}$ Fodder Research Institute Sargodha, Pakistan; ${ }^{5}$ Agronomy (Forage Production) Section, Ayub Agricultural Research Institute, Faisalabad, Pakistan; ${ }^{6}$ Soil Salinity Research Institute, Pindi Bhattian, Punjab, Pakistan.

Abstract | Optimum seeding density and seed size are imperious agronomic practices for improving wheat productivity. Therefore, this field study assessed the impact of diverse seeding rates and seed sizes on performance of wheat. The study was comprised of various seeding rates 100,125 and $150 \mathrm{~kg} \mathrm{ha}^{-1}$ and different seed sizes i.e., bold seed (more than $2.7 \mathrm{~mm}$ ), medium seed (less than $2.7 \mathrm{~mm}$ ) and small seed (less than $2.3 \mathrm{~mm}$ ). The various seed sizes and rates significantly affected performance of wheat crop. For seed sizes maximum LAI, CGR, plant height $(94.32 \mathrm{~cm})$ productive tillers $(\mathrm{PT})\left(364 \mathrm{~m}^{-2}\right)$, thousand grain weight (TGW) (42.67 g), biological yield (BY) (10.61 $\left.\mathrm{t} \mathrm{ha}^{-1}\right)$, grain yield (GY) $\left(4.49 \mathrm{t} \mathrm{ha}^{-1}\right)$ and harvest index (HI) (41.94\%) was obtained with $150 \mathrm{~kg} \mathrm{ha}^{-1}$ seeding rate and lowest LAI, CGR, height $(88.65 \mathrm{~cm})$ PT $(283.11$ $\left.\mathrm{m}^{-2}\right)$, TGW (38.30 g), BY (9.57 $\left.\mathrm{t} \mathrm{ha}^{-1}\right), \mathrm{GY}\left(3.66 \mathrm{t} \mathrm{ha}^{-1}\right)$ and HI (38.66) was noted in seed rate of $100 \mathrm{~kg} \mathrm{ha}{ }^{-1}$. In case of seed size maximum LAI, CGR, plant height $(99.67 \mathrm{~cm})$, PT $\left(348 \mathrm{~m}^{-2}\right)$, TGW (42.67 g), BY (10.68 $\left.\mathrm{t} \mathrm{ha}^{-1}\right)$, GY (4.53 $\left.\mathrm{t} \mathrm{ha}^{-1}\right)$ and HI (42.68\%) was recorded with bold seed (more than $2.7 \mathrm{~mm}$ ) LAI, CGR, plant height $(88.09 \mathrm{~cm})$ PT $\left(294 \mathrm{~m}^{-2}\right)$, TGW $(36.29 \mathrm{~g})$, BY (9.62 $\left.\mathrm{t} \mathrm{ha}^{-1}\right)$, GY (3.61 $\left.\mathrm{t} \mathrm{ha}^{-1}\right)$ and HI (36.92\%) was recorded with small seed size (less than $2.3 \mathrm{~mm}$ ). In conclusion, $150 \mathrm{~kg} \mathrm{ha}{ }^{-1}$ of seed rate and bold seed size can be used under Faisalabad conditions to get the maximum wheat production.

Received | September 22, 2021; Accepted | February 11, 2022; Published | February 24, 2022

*Correspondence | Muhammad Shoaib, Department of Agronomy, University of Agriculture, Faisalabad, 38040, Pakistan; Email: shoaibrehman479@gmail.com,drimran@uaf.edu.pk

Citation | Shoaib, M., M. Nawaz, M. Ilyas, M. Shafique, I. Khan, M.T. Aslam, M.S.A. Bazmi, M. Arshid, G. Ahmad, M. Irfan, M.U. Chattha and M.U. Hassan. 2022. Effect of different seed sizes and seed rates on the growth and productivity of wheat grown under semi-arid conditions. Pakistan Journal of Agricultural Research, 35(1): 122-130.

DOI | https://dx.doi.org/10.17582/journal.pjar/2022/35.1.122.130

Keywords | Bold seeds, Growth, Productivity, Seed rates, Wheat

\section{Introduction}

W Theat is an imperative staple food crop cultivated across the globe owing to its higher nutritional value. The grain wheat crop comprises $68 \%$ carbohydrate, $15.4 \%$ protein, $12.2 \%$ dietary fiber and $1.9 \%$ fat which makes him an imperative food crop for humans (Anjum et al., 2005; Chattha et al., 2017a, b, 2018; Hassan et al., 2019a, 2021). In Pakistan is also a largely consumed food crop and it is planted on 8825 hectares and it is producing 24.94 million tons yield to combat food needs in Pakistan (GoP, 2020). However, wheat productivity is our country is quite lower as compared developed nations (FAOSTAT, 2016). 
There is a big gap among potential and actual yields of wheat crop and this large gap is due to a lack of knowledge about agronomic management and certain factors including late sowing of wheat, non-availability of high-quality certified seeds, poor plant geometry. poor fertilization, improper irrigation technique and high weeds infestation, seed rate and seed size (Sattar et al., 2010; Zain et al., 2017; Hassan et al., 2020a, b; Muhsin et al., 2021; Aslam et al., 2021).

Seed size plays an imperious role in plants growth and final production (Sarker et al., 2007). Many authors reported seed size has substantiated impacts on wheat growth and production (Valério et al., 2009; Muhsin et al., 2021). The seeds with large sizes are considered to have more vigor, germination potential and ability to perform well under wide range of conditions as compared to smaller seeds (Shahwani et al., 2014). Bold seeds also produced the plants with better root growth and leaf area (Aparicio et al., 2002) which in turn increased the overall wheat productivity (Stougaard and Xue, 2005). Contrarily, seeds with small size have poor vigor and poor germination potential which therefore give lower yield (Muhsin et al., 2021). Therefore, seed size can be a viable option to enhance wheat production s (Mustafa et al., 2018).

Seeding density is another imperative factor that determines the plant's ability to acquire natural resources. Optimum plant population affects the wheat production, and it can be achieved using appropriate seed rate (Chaudhry and Hussain, 2001; Zecevic et al., 2014). It is most common practice that the farmer uses a standard seed rate $\left(120 \mathrm{~kg} \mathrm{ha}^{-1}\right)$ irrespective to the cultivar type (Islam et al., 2004). Furthermore, by expecting high yield, irrespective to the recommended seed rate for particular cultivar, they use more seed rate to lower weed pressure in their field that increases their input cost, however, increasing the seed caused substantial reduction in final production (Naseri et al., 2012). Thus, we hypothesize that seed size could have a significant impact on wheat productivity under Faisalabad climatic conditions. Therefore, current research was executed to verify the optimum seed rate along with different seed size to improve wheat productivity grown in semi-arid conditions.

\section{Materials and Methods}

\section{Experimental site}

The current research experiment was conducted during 2018-19 and study area has semiarid and humid climatic conditions during summer and dry conditions during the winter and further climatic conditions are presented in Table 1.The samples depth of 0-30 cm from various parts of the field was taken to determine the different soil properties (Homer and Pratt, 1961). The soil was recognized as sandy loam with $\mathrm{pH}$ of $8.5, \mathrm{EC} 0.42 \mathrm{dS} \mathrm{m}^{-1}$, organic matter $0.72 \%$, total $0.080 \%$ nitrogen, and available phosphorus and potassium 14 and $173 \mathrm{ppm}$, respectively.

\section{Experimental details}

The research trail was carried out using RCBD with factorial arrangement. The study was comprised of three seed rates: $\mathrm{SR}_{1}=100 \mathrm{~kg} \mathrm{ha} \mathrm{h}^{-1}, \mathrm{SR}_{2}=125 \mathrm{~kg} \mathrm{ha}$ 1, $\mathrm{SR}_{3}=150 \mathrm{~kg} \mathrm{ha}{ }^{-1}$ and three sees sizes: sizes: $\mathrm{SS}_{1}=$ bold $(>2.7 \mathrm{~mm}), \mathrm{SS}_{2}=$ medium $(2.7 \mathrm{~mm}), \mathrm{SS}_{3}=$ small $(<2.3 \mathrm{~mm})$.

\section{Seed collection and grading}

Three different sized seeds (bold, medium, small) were divided using two separate sieves. The first seed passes through a sieve of $2.7 \mathrm{~mm}$, the remaining seeds in a sieve are bold seeds, then the seeds that move again through the first sieve of $2.3 \mathrm{~mm}$, the seeds remain above the second filter are the middle seeds, and that seed passes through the second filter is a small seed.

\section{Crophusbandry}

The soil was cultivated two times and planking was done for final sowing. The crop was planted on November 20, 2018 using hand drill with maintaining row spacing $22.5 \mathrm{~cm}$. Fertilizer sources ammonium nitrate $(33 \% \mathrm{~N})$, triple-supar phosphate (TSP) $(46 \%$ $\mathrm{P})$ and sulfate of potash $(50 \% \mathrm{~K})$ was used to supply the suggested amount of NPK 100:75:50 kg ha-1. Fiver number of irrigations including soaking irrigation (4acre inch), and other 4 irrigations of 3-acre inch of each were supplied before the maturity stage of the crop.

\section{Data collection}

The experimental plots were regularly visited and number of seeds emerged on each day were manually counted and time to 50\% emergence (T50) and mean emergence time (MET) were measured by standard methods of Farooq et al. (2005). The wheat plants were harvested from unit area and leaves were separated from stem and leaves sub-sample $(5 \mathrm{~g})$ was taken and leaf area was determined and LAI was measured by methods of Watson (1947). Similarly, harvested samples were oven dried $\left(70^{\circ} \mathrm{C}\right)$ until constant weight 
and CGR was measured by methods of Hunt (1978). We marked ten plants in each plot their heights were taken and averaged. Similarly, productive as well as non productive were counted from a unit area $\left(1 \mathrm{~m}^{2}\right)$. Moreover, ten spikes harvested and spikelet/spike and grains/spike were counted. Lastly, plots were harvested and weighed to determine biological yield and later on threshed to determine to grain yield.

\section{Statistical analysis}

The date of diverse traits was analyzed with Fisher's analysis of variance procedure and LSD test at 5\% was used to determine significant differences amid means (Steel et al., 1997).

\section{Results and Discussion}

The results indicated that seed size has significant impact on the time to $50 \%$ emergence (Days) and mean emergence time (MET) (Days) whereas the seed rate and their interaction had non-significant impact on these traits (Table 1). The bold seeds took the least number of days to complete $50 \%$ emergence $(8.18$ days) and MET (10.79 days) t followed by medium sized seeds whereas, the small seeds took maximum time to complete the $50 \%$ emergence ( 10.74 days) and MET (12.90 days) (Table 1). The results indicated that different seed size classes and seeds rates had significant growth traits (Figures 2 and 3). Bold seeds produced maximum LAI and CGR followed by medium seeds whereas lowest LAI and CGR was noted with use of small seeds (Figures 2 and 3 ). In case of seeds rates the application of $150 \mathrm{~kg} \mathrm{ha}^{-1}$ seed resulted in maximum LAI and CGR followed closely with $150 \mathrm{~kg} \mathrm{ha}{ }^{-1}$ and lowest LAI and CGR was noted $150150 \mathrm{~kg}$ $\mathrm{ha}^{-1}$ seed rate (Figures 2 and 3). LAI and CGR was noted maximum at 75 days after sowing (DAS), after that LAI and CGR both showed the reduction and reached to minimum values at 105 DAS (Figures 2 and 3). The bold seeds have more vigor which ensured the better stand establishment with production of more leaves with better length and width. Therefore, leaves with better length and width have more leaf area and subsequently LAI. Similarly, the better leaf area ensures the better light harvesting which resulted in production of more assimilates and subsequent CGR (Muhsin et al., 2021; Aslam et al., 2021). The current results also coincide with the outcomes of Aslam et al. (2003) and Sattar et al. (2010) they noted that use of $150 \mathrm{~kg} / \mathrm{ha}$ seed rate provided the greatest value of leaf area index and CGR.

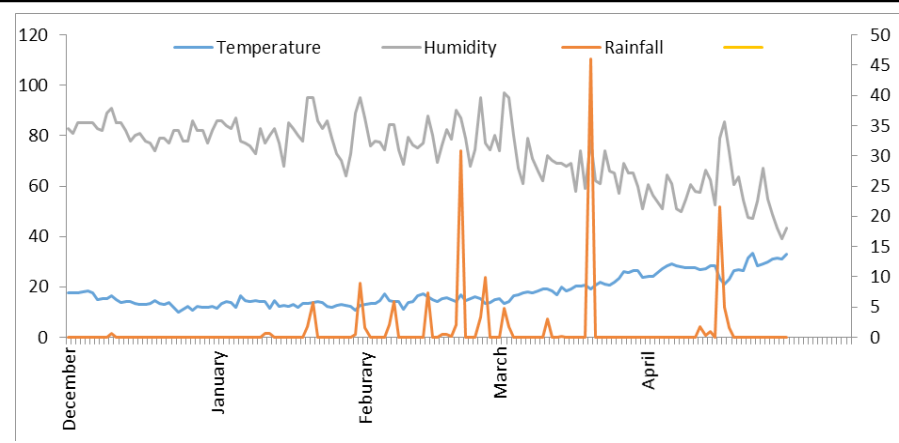

Figure 1: Weather conditions during study period.
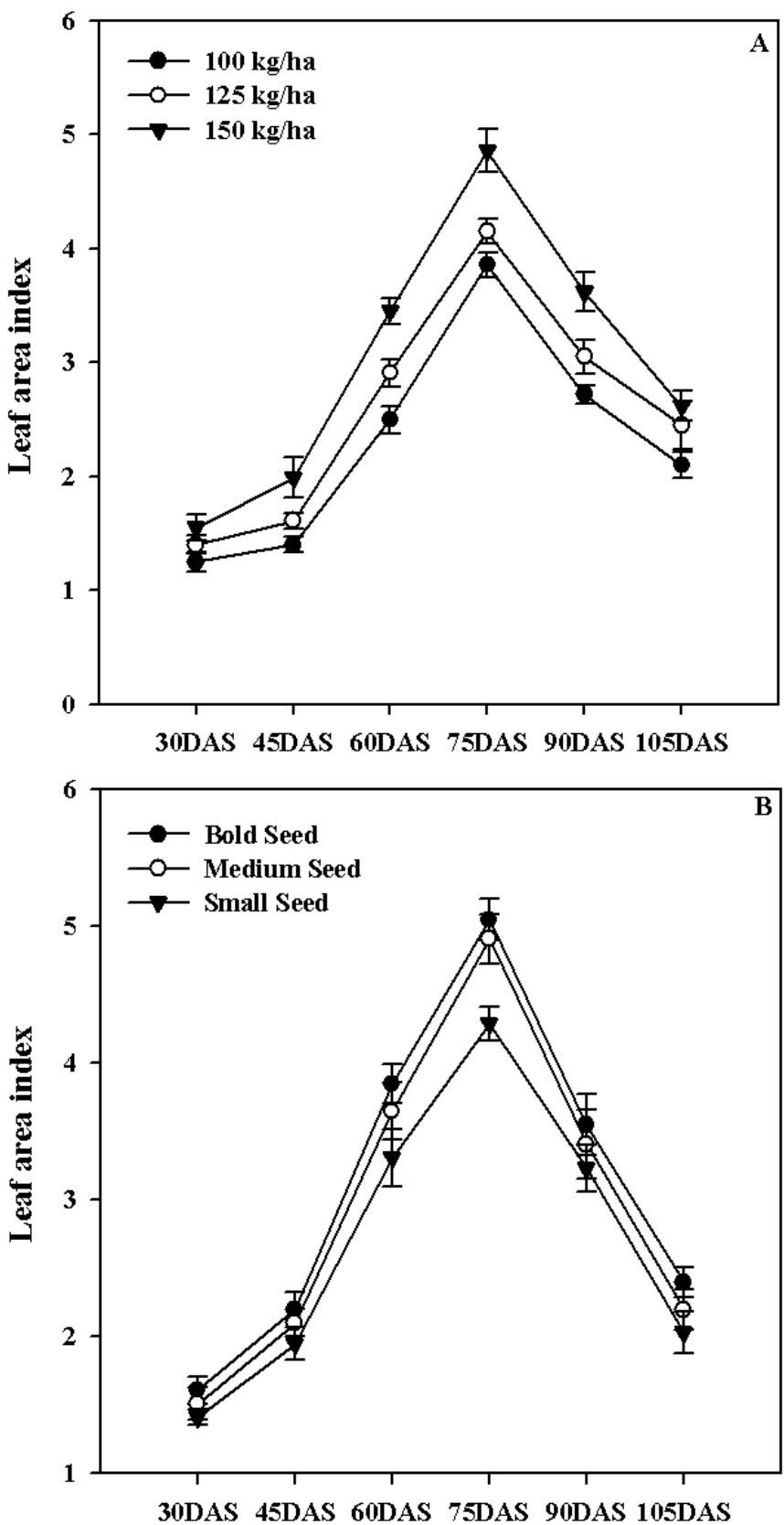

Figure 2: Effect of different rates $(A)$ seed sizes (B) on $L A I$ of wheat crop.

The bold seeds possess high nutritional constituents that help them to emerge more quickly (Gholizadeh, 2012) as compared to smaller seeds. Likewise, we found that in our study we also found that bold seeds 
took less time for $50 \%$ emergence and mean emergence as compared to small and medium seeds. The currents outcomes are in consistence with outcomes of Zareian et al. (2012) they noted that decrease in time to $\mathrm{E}_{50}$ mean emergence by using bold seeds as compared to smaller seeds. The research study disclosed that plant height and spike length was significantly influenced by both different sized seeds and seed rate. Amid seed size, taller plants $(99.67 \mathrm{~cm})$ with longer spikes $(11.37 \mathrm{~cm})$ were recorded from bold seeds followed by medium sized seeds whereas, the least plant height and spike length was recorded from small seeded treatments (Table 1).As for seed rate, dense populated plot (using $150 \mathrm{~kg} \mathrm{ha}^{-1}$ ) produced taller plants (94.32 $\mathrm{cm})$ that was at par with $125 \mathrm{~kg} \mathrm{ha}^{-1}$, contrary, the maximum spike length was noted using $125 \mathrm{~kg} \mathrm{ha}^{-1}$ seed rate that was same with $150 \mathrm{~kg} \mathrm{ha}^{-1}$ (Table 2). Amongst interaction, plants acquired highest plant height $(102.47 \mathrm{~cm})$ in the treatment of bold $\times 150 \mathrm{~kg}$ $\mathrm{ha}^{-1}$ that was same with bold $\times 125 \mathrm{~kg} \mathrm{ha}^{-1}$ after that bold $\times 100 \mathrm{~kg} \mathrm{ha}^{-1}$ (Table 1).

Enlarged plant height and spike length was recorded from bold seeded wheat crop that might be due to early stand establishment to overcome weeds and batter nutrient utilization (Keerio, 2013). Our research findings are confirmatory with Iqbal et al. (2021) who also reported an increased in plant height from bold seeds due to batter mineral usage in vegetative stages. Amid to spike length, our findings are observed closely related to research work reported by Akhter et al. (2017) they reported the maximum spike length with $125 \mathrm{~kg} \mathrm{ha}^{-1}$ seed rate and non-significant increase in spike length with further increase in seed rate.

The bold seeds produced maximum productive tillers $\left(348.89 \mathrm{~m}^{2}\right)$ and lowest non-productive tiller (8.56 $\mathrm{m}^{2}$ ) (Table 1). Conversely, least number of productive tillers $\left(294.22 \mathrm{~m}^{2}\right)$ and maximum un-productive tillers $\left(11.53 \mathrm{~m}^{2}\right)$ were recorded from small sized seeds (Table 1). Maximum productive tillers $\left(364.00 \mathrm{~m}^{2}\right)$ were obtained with $150 \mathrm{~kg} \mathrm{ha}^{-1}$ seeding rate after that 125 $\mathrm{kg} \mathrm{ha}^{-1}$ and the least productive tillers were recorded with using seed rate of $100 \mathrm{~kg}=\mathrm{kg} \mathrm{ha}^{-1}$ (Table 1). Bold seeds produced highest productive tillers compared to medium and small seeds. Bold seeds make sure the optimum number of plants in field, consequently, lead to considerable increase in productive tillers. These findings are affirmed by Muhsin et al. (2021) they also noted that bolder seeds intercept light efficiently and produced more tillers. Moreover, applying more seed rate, the plant population/ area increased that augment the production of productive tillers (Sarker et al., 2009; Akhter et al., 2017).

Table 1: Effect of different size different seed sizes and seeds rates germination and yield traits of wheat crop.

\begin{tabular}{|c|c|c|c|c|c|c|}
\hline Seed size (SS) & T50(Days) & MET (Days) & PH (cm) & PT $\left(\mathbf{m}^{-2}\right)$ & $\operatorname{NPT}\left(m^{-2}\right)$ & SL (cm) \\
\hline Bold & $8.18 \mathrm{C}$ & $10.79 \mathrm{C}$ & $99.67 \mathrm{~A}$ & $348.89 \mathrm{~A}$ & $8.56 \mathrm{C}$ & $11.37 \mathrm{~A}$ \\
\hline Medium & $9.65 \mathrm{~B}$ & $12.19 \mathrm{~B}$ & $87.67 \mathrm{~B}$ & $339.56 \mathrm{~A}$ & 10.14B & $9.60 \mathrm{~B}$ \\
\hline Small & $10.74 \mathrm{~A}$ & $12.90 \mathrm{~A}$ & $88.09 \mathrm{C}$ & $294.22 \mathrm{~B}$ & $11.53 \mathrm{~A}$ & $9.50 \mathrm{~B}$ \\
\hline $\mathrm{LSD} \leq 0.05 \mathrm{P}$ & 0.46 & 0.65 & 2.21 & 15.13 & 0.34 & 0.32 \\
\hline \multicolumn{7}{|l|}{ Seed rate (SR) } \\
\hline $100 \mathrm{~kg} \mathrm{ha}^{-1}$ & 9.35 & 12.01 & $88.65 \mathrm{~B}$ & $283.11 \mathrm{C}$ & 9.83 & $9.64 \mathrm{~B}$ \\
\hline $125 \mathrm{~kg} \mathrm{ha}^{-1}$ & 9.56 & 11.99 & $92.44 \mathrm{~A}$ & $335.56 \mathrm{~B}$ & 10.07 & $10.52 \mathrm{~A}$ \\
\hline $150 \mathrm{~kg} \mathrm{ha}^{-1}$ & 9.67 & 11.89 & $94.32 \mathrm{~A}$ & $364.00 \mathrm{~A}$ & 10.31 & $10.31 \mathrm{~A}$ \\
\hline $\mathrm{LSD} \leq 0.05 \mathrm{P}$ & NS & NS & 2.21 & 15.13 & NS & 0.32 \\
\hline \multicolumn{7}{|l|}{ Interaction $(\mathrm{SS} \times \mathrm{SR})$} \\
\hline Bold $\times 100 \mathrm{~kg} \mathrm{ha}^{-1}$ & 10.42 & 12.69 & $95.27 \mathrm{~b}$ & 298.00 & 8.47 & 10.70 \\
\hline Bold $\times 125 \mathrm{~kg} \mathrm{ha}^{-1}$ & 10.83 & 12.69 & $101.30 \mathrm{a}$ & 365.33 & 8.51 & 11.83 \\
\hline Bold $\times 150 \mathrm{~kg} \mathrm{ha}^{-1}$ & 10.97 & 13.13 & $102.47 \mathrm{a}$ & 383.33 & 8.69 & 11.60 \\
\hline Medium $\times 100 \mathrm{~kg} \mathrm{ha}^{-1}$ & 9.55 & 12.58 & $87.30 \mathrm{~d}$ & 293.33 & 9.82 & 9.26 \\
\hline Medium $\times 125 \mathrm{~kg} \mathrm{ha}^{-1}$ & 9.65 & 12.02 & $87.37 d$ & 350.00 & 10.17 & 9.73 \\
\hline Medium $\times 150 \mathrm{~kg} \mathrm{ha}^{-1}$ & 9.77 & 11.98 & $88.37 \mathrm{~cd}$ & 375.33 & 10.43 & 9.50 \\
\hline Small× $100 \mathrm{~kg} \mathrm{ha}^{-1}$ & 9.35 & 10.76 & $83.40 \mathrm{e}$ & 258.00 & 11.22 & 8.96 \\
\hline Small $\times 125 \mathrm{~kg} \mathrm{ha}^{-1}$ & 8.18 & 11.07 & $88.67 \mathrm{~cd}$ & 291.33 & 11.55 & 10.00 \\
\hline Small $\times 150 \mathrm{~kg} \mathrm{ha}^{-1}$ & 8.27 & 10.56 & $92.13 b c$ & 333.33 & 11.81 & 9.83 \\
\hline $\mathrm{LSD} \leq 0.05 \mathrm{P}$ & NS & NS & 3.82 & NS & NS & NS \\
\hline
\end{tabular}

T50: time to 50\% emergence, MET: mean emergence time, PH: plant height, PT: productive tillers, NPT: non-productive tillers, SL: spike length, NS=non-significant; means with different letters differed at $0.05 \mathrm{P}$. 
Table 2: Effect of different size different seed sizes and seeds rates yield traits and yield of wheat crop.

\begin{tabular}{|c|c|c|c|c|c|c|}
\hline Seed size & SLP & GPS & TGW (g) & GY $\left(t_{h a^{-1}}\right)$ & BY $\left(\mathrm{tha}^{-1}\right)$ & HI (\%) \\
\hline Bold & $18.13 \mathrm{~A}$ & $57.66 \mathrm{~A}$ & $42.67 \mathrm{~A}$ & $4.53 \mathrm{~A}$ & $10.68 \mathrm{~A}$ & $42.68 \mathrm{~A}$ \\
\hline Medium & $16.67 \mathrm{~B}$ & $53.66 \mathrm{~B}$ & $39.34 \mathrm{~B}$ & $4.05 \mathrm{~B}$ & $9.82 \mathrm{~B}$ & $41.28 \mathrm{~A}$ \\
\hline Small & $15.34 \mathrm{C}$ & $43.66 \mathrm{C}$ & $36.29 \mathrm{C}$ & $3.61 \mathrm{C}$ & $9.62 \mathrm{~B}$ & $36.92 \mathrm{~B}$ \\
\hline $\mathrm{LSD} \leq 0.05 \mathrm{P}$ & NS & 2.87 & 0.97 & 0.11 & 0.45 & 1.39 \\
\hline \multicolumn{7}{|l|}{ Seed rate } \\
\hline $100 \mathrm{~kg} \mathrm{ha}^{-1}$ & 16.53 & $48.00 \mathrm{C}$ & $38.30 \mathrm{C}$ & 3.66 & $9.57 \mathrm{~B}$ & $38.66 \mathrm{C}$ \\
\hline $125 \mathrm{~kg} \mathrm{ha}^{-1}$ & 16.92 & $55.11 \mathrm{~A}$ & $40.59 \mathrm{~A}$ & 4.03 & 9.94B & $40.46 \mathrm{~B}$ \\
\hline $150 \mathrm{~kg} \mathrm{ha}^{-1}$ & 16.68 & $51.89 \mathrm{~B}$ & $39.43 \mathrm{~B}$ & 4.49 & $10.61 \mathrm{~A}$ & $41.94 \mathrm{~A}$ \\
\hline $\mathrm{LSD} \leq 0.05 \mathrm{P}$ & 0.32 & 2.87 & 0.97 & 0.11 & 0.45 & 1.39 \\
\hline \multicolumn{7}{|l|}{ Interaction $(\mathrm{SS} \times \mathrm{SR})$} \\
\hline Bold $\times 100 \mathrm{~kg} \mathrm{ha}^{-1}$ & 17.86 & 54.66 & 41.93 & 4.13 & 9.96 & 41.46 \\
\hline Bold $\times 125 \mathrm{~kg} \mathrm{ha}^{-1}$ & 18.56 & 61.33 & 43.59 & 4.46 & 10.45 & 42.67 \\
\hline Bold $\times 150 \mathrm{~kg} \mathrm{ha}^{-1}$ & 17.96 & 57.00 & 42.50 & 5.11 & 11.63 & 43.93 \\
\hline Medium $\times 100 \mathrm{~kg} \mathrm{ha}^{-1}$ & 16.50 & 49.00 & 38.21 & 3.82 & 9.75 & 39.17 \\
\hline Medium $\times 125 \mathrm{~kg} \mathrm{ha}^{-1}$ & 16.60 & 58.33 & 40.53 & 4.11 & 9.88 & 41.59 \\
\hline Medium $\times 150 \mathrm{~kg} \mathrm{ha}^{-1}$ & 16.90 & 53.66 & 39.28 & 4.24 & 9.84 & 43.09 \\
\hline Small $\times 100 \mathrm{~kg} \mathrm{ha}^{-1}$ & 15.23 & 40.33 & 34.77 & 3.15 & 8.99 & 35.04 \\
\hline Small $\times 125 \mathrm{~kg} \mathrm{ha}^{-1}$ & 15.60 & 45.66 & 37.58 & 3.53 & 9.51 & 37.11 \\
\hline Small $\times 150 \mathrm{~kg} \mathrm{ha}^{-1}$ & 15.20 & 45.00 & 36.52 & 4.01 & 10.38 & 38.63 \\
\hline $\mathrm{LSD} \leq 0.05 \mathrm{P}$ & NS & NS & NS & 0.19 & NS & NS \\
\hline
\end{tabular}

SLP: spikelet's/spike, GPS: grains per spike, TGW: 1000 grain weight, GY: grain yield, BY: biological yield, HI: harvest index, NS=nonsignificant; means with different letters differed at 0.05 P.

Different seed size significantly affected the spikelets/ spike whilst varying seed rate showed no significant impact on spikelets. The maximum spikelets/ spike (18.13) was counted from bold seeds followed by medium sized seeds, and the small seeds remained at lowest position with minimum spikelet's (15.34) (Table 2). Our findings suggested that bold sized seeds completed early vegetative stage by emerging more quickly to assemble high assimilates and thus, more produced more spikelets/ spike. The current outcomes are same with Gadisa (2019) and Neugschwandtner et al. (2019) they also noted the use bold seeds improved the productions of spikelet's in winter wheat. Various seeding rates and seed sizes had significant impact on the grains/spike and thousand grain weights was found significant (Table 2) More rains/spike (57.66) and TGW (42.67g) was noticed from bold seeded crop followed by medium sized seeds and the least grain numbers per spike (43.66) along with 1000 grain weight $(36.29 \mathrm{~g})$ was recorded from small size seeds (Table 2). Amid seed rate, the use of $125 \mathrm{~kg}$ $\mathrm{ha}^{-1}$ seed rate showed highest number of grains/spike (55.11) and TGW (40.59g) and lowest grains/spike (48) and 1000 grain weight (38.30g) was noted by utilizing $100 \mathrm{~kg} \mathrm{ha}^{-1}$ seed rate (Table 2).

Bold seeds significantly increased grains/spike and 1000 grains weight that could be due to high food reserve present in bold seeds compared to other medium and small seeds, which enables the seedling to produce more productive tillers, lower the weed density to create more surface area to intercept photosynthetic active radiation (PAR) that resulted in increase in production of more grains with more weight (Iqbal et al., 2021). Our observation showed that thousand grains weight was increased with use of optimum seed rate. The current outcomes are comparable with findings of Baloch et al. (2010) they also noted increase in TGW with use of optimum seed whereas 1000 seed weight decreased with increasing the seed rate (Laghari et al., 2011; Akhter et al., 2017). The maximum grain yield $\left(4.53 \mathrm{t} \mathrm{ha}^{-1}\right)$ produced by bold seeds followed by medium size seeds and the low grain yield $\left(3.61 \mathrm{t} \mathrm{ha}^{-1}\right)$ was recorded with small size (Table 2). Amongst seed rate, the use of high seed rate $\left(150 \mathrm{~kg} \mathrm{ha}^{-1}\right)$ increases the grain yield up to 4.49 $\mathrm{t} \mathrm{ha}^{-1}$ followed by $125 \mathrm{~kg} \mathrm{ha}^{-1}$ seed rate (Table 2). 

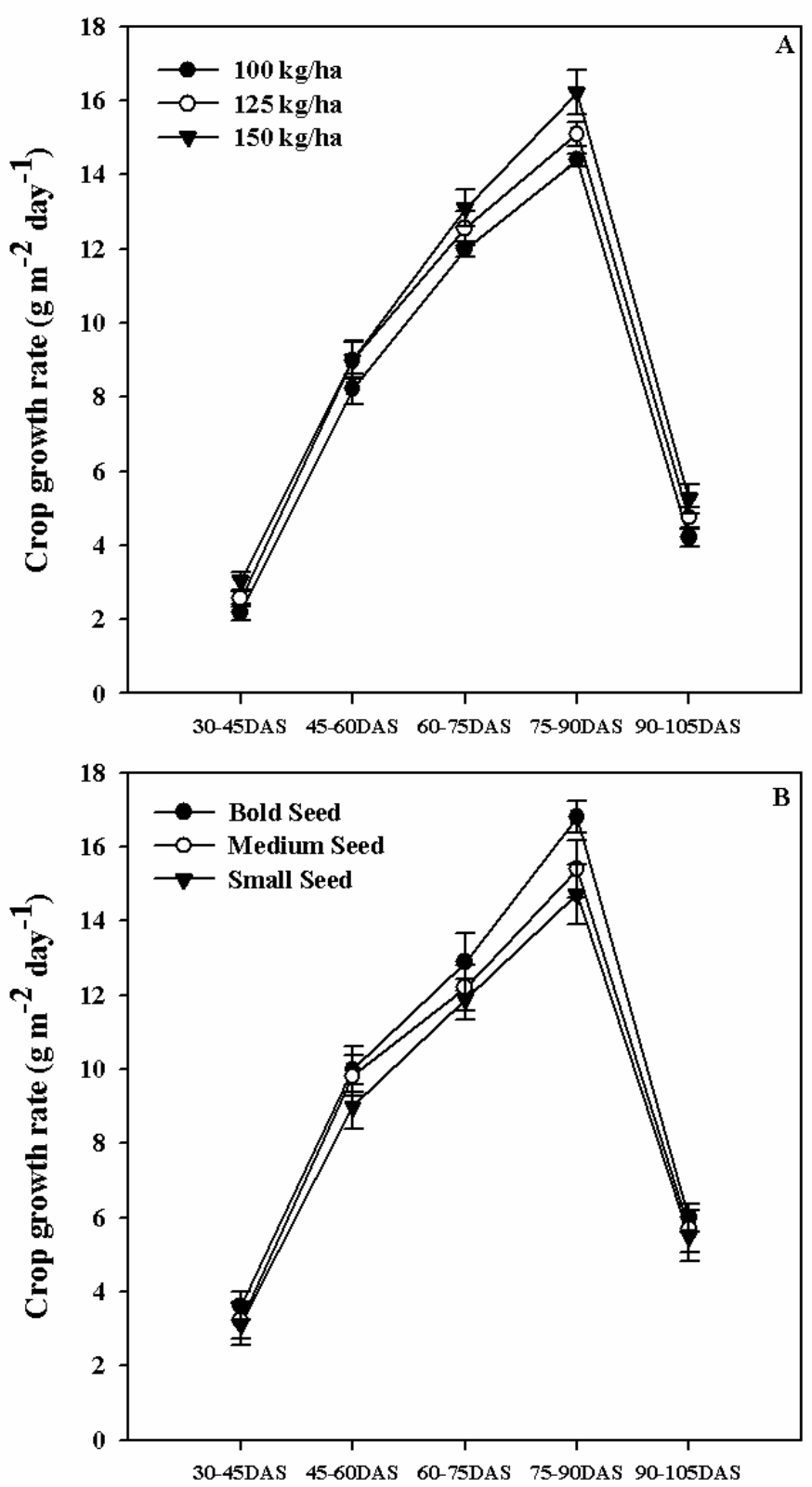

Figure 3: Effect of different rates (A) seed sizes (B) on CGR of wheat crop.

The maximum yield in bolder seeds might be due to higher LAI which ensure the better assimilates production and thus improved the tillers production, spikes, grains/spike and grain weight all of these contributed to significant increase in grain yield (Shahwani et al., 2014; Gadisa, 2019; Tenikecier and Genctan, 2020). The maximum biomass production $\left(10.68 \mathrm{t} \mathrm{ha}^{-1}\right)$ was noted from bold seeds followed by medium size a seed (Table 2). In case of diverse seeding rates maximum biological yield (10.61 tha $\left.{ }^{1}\right)$ was attained when high seed rate $\left(150 \mathrm{ha}^{-1}\right)$ was used followed by 125 and $100 \mathrm{~kg} \mathrm{ha}^{-1}$ seed rates that were observed statistically similar for each treatment (Table 2). The remarkable increase in biological yield was noted from the crop sown with bold size seeds which is supported by the findings reported by
Keerio (2013) they also stated bold seeds ensured the better LAI, assimilates production and which in turn increased the biomass production. Highest biological yield was obtained with increasing seeding rate that can be due to more productive tillers and subsequently increased biological yield (Akhter et al., 2017).

Different seed rates applying in a combination to varying seed size significantly affected the harvest index (HI) of the crop. The highest HI (42.68\%) was noted from the crop sown with bold seeds and observed similar to the crop sown with medium seeds that was followed by small seeds (Table 2). In addition, the use of high seed rate $\left(150 \mathrm{~kg} \mathrm{ha}^{-1}\right)$ ensured maximum HI (41.94\%) lowest harvest index (38.66\%) was obtained from the use of least seed rate $\left(100 \mathrm{~kg} \mathrm{ha}^{-1}\right)$ (Table 2). The HI is product of grain and biological yield therefore, maximum $\mathrm{HI}$ in bold seeds with use of seed rate at $150 \mathrm{~kg} \mathrm{ha}^{-1}$ was due to maximum grain and biological yields.

\section{Conclusions and Recommendations}

The results showed that bold seeds markedly improved final production owing to vigorous germination and increase in yield contributing traits. Moreover, application of seed rate at the $150 \mathrm{~kg} \mathrm{ha}^{-1}$ remained the top performer in improving yield and yield associated traits. Therefore, use of bold seeds and application of $150 \mathrm{~kg} \mathrm{ha}{ }^{-1}$ seed rate can significantly improve the wheat growth and productivity.

\section{Novelty Statement}

Limited information is available about the effect of seed sizes on the growth and yield of wheat crop. Therefore, this study was conducted to verify the effect of different seed sizes along with different seed rates on productivity of wheat crop.

\section{Autor's Contribution}

Muhammad Shoaib: Conducted the experiment.

Imran Khan and Muhammad Umer Chattha: $\mathrm{Su}^{-}$ pervised.

Muhammad Nawaz, Muhammad Ilyas, Muhammad Shafique, Muhammad Talha Aslam, Muhammad Sultan Ali Bazmi, Muhammad Arshid, Ghulam Ahmad, Muhammad Irfan and Muhammad Umair Hassan: Reviewed and edited the manuscript. 
Conflict of interest

The authors have declared no conflict of interest.

\section{References}

Akhter, M.M., A.E. Sabagh, M.N. Alam, M.K. Hasan, E. Hafez, C. Barutçular and M.S. Islam. 2017. Determination of seed rate of wheat (Triticum aestivum L.) varieties with varying seed size. Sci. J. Crop Sci., 6: 161-167.

Anjum, F.M., I. Ahmad, M.S. Butt, M.A. Shiekh and I. Pasha. 2005. Amino acid composition of spring wheat and losses of lysine during chapati baking. J. Food Comp. Anal., 18: 523-532. https://doi.org/10.1016/j.jfca.2004.04.009

Aparicio, N., D. Villegas, J.L. Araus, R. Blanco and C. Royo. 2002. Seedling development and biomass as affected by seed size and morphology in durum wheat. J Agric. Sci., 139: 143-150. https://doi.org/10.1017/S0021859602002411

Aslam, M.U., M.U. Chattha, I. Khan, R. Maqbool, M.B. Chattha, F. Hussan, M. Nawaz, M.S. Hanif, M.A. Ayub, M.T. Aslam, M. Khan and M.U. Hassan. 2021. Effect of different organic mulches and nitrogen sources on the productivity of wheat crop grown in semi-arid area.Pak.J.Agric. Res., 34: 648-655. https://doi. org/10.17582/journal.pjar/2021/34.3.648.655

Baloch, S.M., I.T. Shah, M.A. Nadim, M.I. Khan and A.A. Khakwani. 2010. Effect of seeding density and planting time on growth and yield attributes of wheat. J. Anim. Plant Sci., 20: 239240.

Chattha,M.U.,H.Ali, M.U.Chattha,M.U.Hassan, M.B. Chattha, M. Nawaz and S. Hussain. 2018. Combined application of distillery spent wash, bio-compost and inorganic fertilizers improves growth, yield and quality of wheat. J. Anim. Plant Sci., 28: 1112-1120.

Chattha, M.U., M.B. Chattha, I. Khan, U. Anwar, M.U. Hassan, M. Nawaz, S.A. Anjum, A. Mahmood and S. Mirza. 2017a. Effect of seeding rate and seed soaking duration on productivity of relay-intercropped wheat in cotton. Pak. J. Sci., 69: 190-194.

Chattha, M.U., M.U. Hassan, I. Khan, M.B. Chattha, A. Mahmood, M. Nawaz, S. Khan, M.N. Subhani and M. Kharal. 2017b. Biofortification of wheat cultivars to combat zinc deficiency. Front. Plant Sci., 8: 281. https:// doi.org/10.3389/fpls.2017.00281
Chaudhry, A.U. and I. Hussain. 2001. Influence of seed size and seed rate on phenology, yield and quality of wheat. Pak. J. Biol. Sci., 4: 414-416. https://doi.org/10.3923/pjbs.2001.414.416

Dar, F.A., M. Gera and N. Gera. 2002. Effect of seed grading on germination pattern of some multi-purpose tree species of Jammu region. Indian For., 128: 509-512.

FAOSTAT (Food and Agriculture Organization). 2016. FAO production yearbook for the year 2015-16. Rome, Italy.

Farhoudi, R. and M. Motamedi. 2010. Effect of salt stress and seed size on germination and early seedling growth of safflower (Carthamus tinctorius L). Seed Sci. Technol., 38: 73-78. https://doi.org/10.15258/sst.2010.38.1.07

Farooq, M., S.M.A. Basra, B.A. Saleem, M. Nafees and S.A. Chishti. 2005. Enhancement of tomato seed germination and seedling vigor by osmopriming. Pak. J. Agric. Sci., 42: 36-41.

Gadisa,A.,2019. Review on the effect of seed source and size on grain yield of bread wheat (Tritium aestivum L.). J. Ecol. Nat. Resour., 3: 000155. https://doi.org/10.23880/jenr-16000155

Gholizadeh, M.E., 2012. Assessment of seedling green percentage, seedling green rate and seedling emergence index of corn S. C704 source effect and seed size in Khuzestan. Aust. J. Basic Appl. Sci., 6: 490-494.

Government of Pakistan, 2020. Economic survey of Pakistan. 2019-20. Economic Advisors Wing, Ministry of Finance. Government of Pakistan, Islamabad.

Guberac, V., S. Maric, M. Bede, J. Kovačevic, G. Drezner and A. Lalic. 2005. Grain yield of new Croatian winter wheat cultivars in correlation with sowing rate. Cereal Res. Commun., 33: 777-784. https://doi.org/10.1556/ CRC.33.2005.2-3.148

Hassan, M.U, M. Aamer, M.U. Chattha, T. Haiying, B. Shahzad, L. Barbanti, M., Nawaz, A. Rasheed, A. Afzal, Y. Liu and H. Guoqin. 2020a. The critical role of zinc in plants facing the drought stress. Agriculture, 10: 396. https:// doi.org/10.3390/agriculture10090396

Hassan, M.U., M. Aamer, M. Nawaz. A. Rehman, M.T. Aslam, U. Afzal. M.A. Shahzad, M.A. Ayub, M. Qiaying, S. Qitao and H. Guoqin. 2021. Agronomic bio-fortification of wheat to combat zinc deficiency in developing countries. Pak. J. Agric. Res., 34: 201-207. https://doi. 
org/10.17582/journal.pjar/2021/34.1.201.217

Hassan, M.U., M.U. Chattha, A. Ullah, I. Khan, A. Qadeer, M. Aamer, A.U. Khan, F. Nadeem and T.A. Khan. 2019a. Agronomic biofortification to improve productivity and grain $\mathrm{Zn}$ concentration of bread wheat. Int. J. Agric. Biol., 21: 615-620.

Hassan, M.U., M.U. Chattha, I. Khan, M.B. Chattha, L. Barbanti, M. Aamer, M.M. Iqbal, M. Nawaz, A. Mahmood, A. Ali and M.T. Aslam. 2020b. Heat stress in cultivated plants: Nature, impact, mechanisms, and mitigation strategies. A review. Plant Biosys., 155: 211234. https://doi.org/10.1080/11263504.2020. 1727987

Homer, D.C. and Pratt, P.F., 1961. Methods of analysis for soils, plants and waters. Davis: University of California, Davis.

Hunt, R. 1978. Plant growth analysis. The institute Biology's studies in Biology. Edward Arnold (Pub) Ltd, London, 96: 8-38.

Iqbal, J., A. Zohaib, M. Hussain, A. Bashir, M. Hamza, W. Muzaffer, M.T. Latif and N. Faisal. 2020. Effect of Seed Rate on Yield Components and Grain Yield of Ridge Sown Wheat Varieties. Pak. J. Agric. Res., 33(3): 508-515. https://doi.org/10.17582/journal. pjar/2020/33.3.508.515

Iqbal, M.M., I. Khan, M. Sanaullah and M. Farooq. 2021. Influence of seed size on the growth, productivity, and water use efficiency of bread wheat planted by different methods. Arch. Agron. Soil Sci., 67: 354-370. https://doi.org/ 10.1080/03650340.2020.1729979

Islam, M.S., M.A. Sattar, M.M. Rahman, M.A. Qayum, M.S. Alam and R.A. Mustafi. 2004. Krishi Projukti Hatboi (Handbook on Agrotechnology), $3^{\text {rd }}$ Ed. Bangladesh Agricultural Research Institute, Gazipur- 1701, Bangladesh. pp. 560.

Jan,A.,I.Hamid and M.T.Jan.2000. Yield and yield components of wheat as influenced by seed rate and sowing dates. Pak. J. Biol. Sci., 3: 323-325. https://doi.org/10.3923/pjbs.2000.323.325

Keerio, M.U., 2013. Influence of seed size and seedling rate on growth and yield of wheat (Doctoral dissertation, M. Sc. Thesis submitted to Sindh Agriculture University Tandojam).

Kristó, I., K. Gyuris, M. Torma, M. Hódi-Szél and I.M. Petróczi. 2007. Investigation of sowing date and seeding rate on the yield of winter wheat. Cereal Res. Commun., 35: 685-688. https://doi.org/10.1556/CRC.35.2007.2.130

Laghari, G.M., F.C. Oad, S. Tunio, Q. Chachar, A.W. Gandahi, M.H. Siddiqui. 2011. Growth and yield attributes of wheat at different seed rates. Sarhad J. Agric., 27: 177-183.

Lloveras, J., J. Manent, J. Viudas, A. López and P. Santiveri. 2004. Seeding rate influence on yield and yield components of irrigated winter wheat in a Mediterranean climate. Agron. J., 96: 1258-1265. https://doi.org/10.2134/ agronj2004.1258

Malik, A.U., M. Ahmad alias, H.A. Bukhsh and I. Hussain. 2009. Effect of seed rates sown on different dates on wheat under agro-ecological conditions of Dera Ghazi Khan. J. Anim. Plant Sci., 19: 126-129.

Maric, S., V. Guberac, G. Drezner, S. Petrovic, T. Cupic and V. Brandic. 2008. Effects of testing environments and crop density on winter wheat yield. In: (ed. R. Appels). Proc. of the $11^{\text {th }}$ International Wheat Genetics Symposium held on 24-29 August 2008, Brisbane, Queensland, Australia.pp. 684-686

Muhsin, M., M. Nawaz, I. Khan, M.B. Chattha, S. Khan, M.T. Aslam, M.M. Iqbal. M.Z. Amin, U. Anwar, M.U. Hassam and M.U. Chattha. 2021. Efficacy of seed size to improve field performance of wheat under late sowing conditions. Pak. J. Agric. Res., 34: 247-253. https://doi.org/10.17582/journal. pjar/2021/34.1.247.253

Mustafa, A., R. Ahmad, M. Farooq and A. Wahid. 2018. Effect of seed size and seed priming on stand establishment, wheat productivity and profitability under different tillage systems. Int. J. Agric. Biol., 20: 1710-1716.

Muzaffar, W., R. Ahmad, M. Hussain, M. Farooq and A. Wakeel. 2019. Influence of seed priming and sowing methods on growth and productivity of wheat cultivars differing in seed size in ricewheat cropping system of Punjab, Pakistan. Int. J. Agric. Biol., 21: 803-809.

Naseri, R., A. Soleymanifard, H. Khoshkhabar, A. Mirzaei and K. Nazaralizadeh. 2012. Effect of plant density on grain yield, yield components and associated traits of three durum wheat cultivars in Western Iran. Int. J. Agric. Crop Sci., 4: 79-85.

Neugschwandtner, R.W., S. Papst, J. Kemetter, 
H. Wagentristl, O. Sedlář and H.P. Kaul. 2019. Effect of seed size on soil cover, yield, yield components and nitrogen uptake of two-row malting barley. Bodenkultur J. Land Manage. Food Environ., 70: 89-98. https://doi. org/10.2478/boku-2019-0008

Otteson, B.N., M. Mergoum and J.K. Ransom. 2008. Seeding rate and nitrogen management on milling and baking quality of hard red spring wheat genotypes. Crop. Sci., 48: 749-755. https://doi.org/10.2135/cropsci2007.08.0473

Razzaque, M.A., M.A. Sattar, M.S. Amin, M.A. Qayum and M.S. Alam. 2000. Krishi Projukti Hathoi (Handbook on Agro-technology), 2 ${ }^{\text {nd }}$ Ed. Bangladesh Agricultural Research Institute, Gazipur-1701, Bangladesh. pp. 464.

Royo, C., A. Ramdani, M. Moragues and V. Villegas. 2006. Durum wheat under mediterranean conditions as affected by seed size. J. Agron. Crop Sci., 192: 257-266. https:// doi.org/10.1111/j.1439-037X.2006.00215.x

Sarker,M.A.Z.,P.K.Malaker,M. Bodruzzaman and N.C.D.Barma.2009. Effect of management and seed rate on the performance of wheat varieties with varying seed sizes. Bangladesh J. Agric. Res., 34: 481-492. https://doi.org/10.3329/ bjar.v34i3.3975

Sarker, M.A.Z., P.K. Malaker, M. Saifuzzaman and D.B. Pandit. 2007. Effect of variety and seed rate on the yield of wheat. Bangladesh J. Agric. Enviorn., 3: 75-82.

Sattar, N., D. Preiss, H.M. Murray, P. Welsh, B.M. Buckley, A.J. de Craen, S.R.K. Seshasai, J.J. McMurray, D.J. Freeman, J.W. Jukema and P.W. Macfarlane. 2010. Statins and risk of incident diabetes: a collaborative meta-analysis of randomised statin trials. Lancet, 375: 735-742. https://doi.org/10.1016/S01406736(09)61965-6

Schillinger, W.F., 2005. Tillage method and sowing rate relations for dryland spring wheat, barley, and oat. Crop Sci., 45: 2636-2643. https://doi. org/10.2135/cropsci2005.04-0016

Shahwani, A.R., S.U. Baloch, S.K. Baloch, B. Mengal, W. Bashir, H.N. Baloch, R.A. Baloch, A.H. Sial, S.A. Sabiel, K. Razzaq and A.A. Shahwani. 2014. Influence of seed size on germinability and grain yield of wheat (Triticum aestivum L.) varieties. J. Nat. Sci. Res., 4: 147155.
Sinclair, T.R. and P.D. Jamieson. 2006. Grain number, wheat yield, and bottling beer: an analysis. Field Crop Res., 98: 60-67. https:// doi.org/10.1016/j.fcr.2005.12.006

Steel, R.G.D., Torrie, J.H. and Dickey, D.A. 1997. Principles and procedures of statistics: A biometric approach, 3rd edn. McGraw Hill Book Co. Inc., New York.

Stougaard, R.N. and Q. Xue. 2005. Quality versus quantity: spring wheat seed size and seeding rate effects on Avena fatua interference, economic returns and economic thresholds. Weed Res., 45: 351-360. https://doi.org/10.1111/j.13653180.2005.00468.x

Tenikecier, H.S. and T. Genctan. 2020. Effect of endosperm and seed size on some yield and quality characteristics of wheat (Triticum aestivum L.). Curr. Trends Nat. Sci., 9: 132-141. https://doi.org/10.47068/ctns.2020.v9i17.015

Valério, I.P., F.I. Félix de Carvalho, A. Costa de Oliveira, G. Benin, V. Queiroz de Souza and A. de Almeida Machado. 2009. Seeding density in wheat genotypes as a function of tillering potential. Sci. Agric., 66: 28-39. https://doi. org/10.1590/S0103-90162009000100004

Wajid, A., A. Hussain, A. Ahmad, A.R. Goheer, M. Ibrahim and M. Mussaddique. 2004. Effect of sowing date and plant population on biomass, grain yield and yield components of wheat. Int. J. Agric. Biol., 6: 1003-1005.

Watson, D.J. 1947. Comparative physiological studies in the growth of field crops. I: variation in net assimilation rate and leaf area between species and varieties, and within and between years. Ann. Bot., 11: 41-76.

Zain, M., I. Khan, M.U. Chattha, R.W.K. Qadri, S.A. Anjum, M.U. Hassan, A. Mahmood and M. Ilyas. 2017. Foliar applied thiourea at different growth stages modulated late sown wheat. Pak. J. Sci., 69: 39-43.

Zareian, A., L. Yari, F. Hasani and G.H. Ranjbar. 2012. Field performance of three wheat (Triticum aestivum L.) cultivars in various seed sizes. World Appl. Sci. J., 16: 202-206.

Zecevic, V., J. Boskovic, D. Knezevic and D. Micanovic. 2014. Effect of seeding rate on grain quality of winter wheat. Chil. J. Agric. Res., 74: 23-28. https://doi.org/10.4067/ S0718-58392014000100004 